\title{
Is Combined Pretransplantation Seropositivity of Kidney Transplant Recipients for Cytomegalovirus Antigens (pp150 and pp28) a Predictor for Protection against Infection?
}

\author{
S. Essa ${ }^{a} \quad$ A. Pacsa ${ }^{a} \quad$ T. Said $^{b} \quad$ M.R.N. Nampoory ${ }^{b} \quad$ R. Raghupathy ${ }^{a} \quad$ K.V. Johny ${ }^{b}$ \\ W. Al-Nakiba M. Al-Mosawy ${ }^{b}$ \\ ${ }^{a}$ Department of Microbiology, Faculty of Medicine, Kuwait University, and ${ }^{b}$ Hamad Al-Essa Organ Transplant Center, \\ Ministry of Health, Kuwait
}

\section{Key Words}

Kidney transplantation - Cytomegalovirus infection •

Antibody responses $\cdot$ Peptide antigens

\begin{abstract}
Objective: This study was aimed at detecting antibodies to the antigens which may contribute to protection against cytomegalovirus (CMV) infection after organ transplantation. Materials and Methods: A total of 203 kidney transplant patients were enrolled in the study. Based on CMV antigenemia assay, 23 patients were antigen-positive and of the remaining 180 antigen-negative patients, 46 were selected as controls matched for age, gender and source of kidney. The 69 kidney recipients (KR) had CMV antibody due to previous infection and were followed up for a period of 6 months after transplantation for the development of active CMV infections by the antigenemia assay. Antibody responses to five CMV-related peptide antigens (pp65, gB, pp150, pp28 and pp38) were investigated by enzyme immunoassay and their presence was correlated with the results of the CMV antige-
\end{abstract}

This research was supported by Kuwait University grant No. $\mathrm{MI03/02.}$

\section{KARGER}

Fax +41613061234

E-Mail karger@karger.ch

www.karger.com
(C) 2007 S. Karger AG, Basel

1011-7571/08/0171-0066\$24.50/0

Accessible online at:

www.karger.com/mpp nemia assay. Results: Of the five CMV-related peptide antigens, only gB antigen showed response to the antibody in 10/23 (43.5\%) antigen-positive patients and 9/46 antigennegative patients and the difference was statistically significant $(p=0.048)$. On the other hand, there was no significant difference in antibody responses between the antigen-positive and antigen-negative KR to the other four CMV peptide antigens ( $p>0.05$ ). However, among the antigen-positive KR there was only 1 patient who had antibodies to both pp150 and pp28 antigen, while among the antigen-negative KR, 22 of $46(47.8 \%)$ had the antibodies $(p<0.001)$. Conclusion: The findings suggest that the combined presence of antibodies against the pp150 and pp28 antigens may indicate a lower risk of CMV reactivation after kidney transplantation.

Copyright $\odot 2007$ S. Karger AG, Basel

\section{Introduction}

A common complication following organ transplantation is infection with cytomegalovirus (CMV) $[1,2]$, a ubiquitous member of the $\beta$-herpesvirus group. CMV infection occurs in the majority of humans, mainly during the first two decades of life. Although the main host defense against $\mathrm{CMV}$ is cell-mediated immunity, several 
Table 1. Age, source of kidney and gender distribution in antigen-positive and -negative kidney transplant recipients

\begin{tabular}{|c|c|c|c|c|c|c|c|}
\hline \multirow[t]{2}{*}{ Age } & \multicolumn{4}{|c|}{ Source of kidney } & \multicolumn{3}{|l|}{ Gender } \\
\hline & $\begin{array}{l}\text { cadaver } \\
\text { pos/neg }\end{array}$ & $\begin{array}{l}\text { LR } \\
\text { pos/neg }\end{array}$ & $\begin{array}{l}\text { LUR } \\
\text { pos/neg }\end{array}$ & $\begin{array}{l}\text { total } \\
\text { pos/neg }\end{array}$ & $\begin{array}{l}\text { female } \\
\text { pos/neg }\end{array}$ & $\begin{array}{l}\text { male } \\
\text { pos/neg }\end{array}$ & $\begin{array}{l}\text { total } \\
\text { pos/neg }\end{array}$ \\
\hline$<20$ years & $0 / 0$ & $0 / 0$ & $2 / 4$ & $2 / 4$ & $1 / 2$ & $1 / 2$ & $2 / 4$ \\
\hline 21-40 years & $3 / 6$ & $0 / 0$ & $0 / 0$ & $3 / 6$ & $3 / 6$ & $0 / 0$ & $3 / 6$ \\
\hline $41-60$ years & $3 / 6$ & $0 / 0$ & $10 / 20$ & $13 / 26$ & $7 / 14$ & $6 / 12$ & $13 / 26$ \\
\hline$>60$ years & $0 / 0$ & $1 / 2$ & $4 / 8$ & $5 / 10$ & $2 / 4$ & $3 / 6$ & $5 / 10$ \\
\hline Total & $6 / 12$ & $1 / 2$ & $16 / 32$ & $23 / 46$ & $13 / 26$ & $10 / 20$ & $23 / 46$ \\
\hline
\end{tabular}

Pos = Positive; neg = negative LR = life related LUR = life unrelated.

studies suggest that humoral immunity and particularly the level of neutralizing virus-specific antibodies may also modify the disease caused by this virus $[3,4]$. The deleterious effects of CMV in transplant recipients result from direct viral invasion of various organ systems $[5,6]$. Currently the treatment of CMV disease in solid-organ transplant recipients consists of the administration of intravenous ganciclovir for 3 weeks; however, CMV disease still occurs after the completion of oral antiviral prophylaxis $[7,8]$. Despite the advent of antiviral chemotherapy, CMV infections remain a significant cause of morbidity in organ transplant patients, including kidney recipients (KR).

Controlling an active CMV infection requires a joint action of both cell- and antibody-mediated immunity [917] and this is well maintained in healthy individuals. However, in transplant patients the immune responsiveness is hampered by the immunosuppressive therapy. Despite this fact, immunity still plays a role in determining the outcome of CMV infection in KR.

The combination of proteins that should be included in the antigen mixture for investigation of protective cell-mediated and humoral immunity is not fully defined. However, a number of CMV proteins may be good candidates [18-21]. The tegument protein pp150 (UL32) is recognized by most antigen-positive individuals during activated viral infections [22,23]. On the other hand, the major tegument protein pp65 (UL83) is recognized early during infection and can stimulate $\mathrm{T}$ cell responses $[24,25]$. Other $\mathrm{CMV}$ proteins that evoke cellular responses include the tegument proteins pp28 (UL99) and major tegument protein (UL48), viral glycoprotein gB (UL55), pp38 (UL80a), peptide 981-1003 (UL86), IE2 (UL122), IE1 (UL123) and pp71 (UL82) [26-29].
Immunological factors that confer protection against disease development are not well characterized. Identifying those antigens that provoke protective humoral immunity against CMV infection and/or disease may help to provide markers for categorizing patients into highand low-risk groups for developing CMV-related complications. In this respect we investigated the antibody responses of KR to the peptide antigens gB, pp150, pp65, pp28 and pp38.

\section{Subjects and Methods}

\section{Study Population}

A total of $203 \mathrm{KR}$ patients were enrolled in the study. Based on CMV antigenemia as described below, $23 \mathrm{KR}$ were antigen-positive and of the remaining 180 antigen-negative $\mathrm{KR}, 46$ were selected as controls matched for age, gender and source of kidney as shown in table 1.

The $69 \mathrm{KR}$ (42 male and 27 female) were monitored over a period of 6 months from the day of transplantation. The average age for men and women was 39 years with a range from 16 to 72 . All recipients and donors were CMV IgG-positive prior to transplantation. KR were assigned to receive induction antithymocyte globulin and maintenance immunosuppression (prednisolone, cyclosporine, and mycophenolate mofetil). Prophylactic intravenous ganciclovir was administered for 2 weeks at a dose of $5 \mathrm{mg}$ / $\mathrm{kg} /$ day (adjusted to kidney function) starting from the day of surgery. CMV disease was treated with intravenous ganciclovir $5 \mathrm{mg} / \mathrm{kg}$ twice daily for 21 days. Patients with systemic manifestations continued ganciclovir therapy for 3 months. Blood samples from the patients were collected as follows: one sample before transplantation, 4 samples during the first month, 4 samples during the second and third months and finally 3 samples $4-6$ months after transplantation. 
CMV Antigenemia Assay

The antigenemia assay was carried out as described earlier [30]. Blood samples were separated by dextran sedimentation method and pp65 antigen was detected according to the procedure recommended by the manufacturer (INCSTAR Corp., Salt Lake City, Utah, USA). The number of cells containing the CMVspecific pp65 antigen was counted under a light microscope $(\times 400)$ and samples containing $\geq 5$ cells/50,000 with the pp65 antigen were considered positive for current CMV replication.

\section{Antigens for Enzyme Immunoassay (EIA)}

Five peptide antigens (Thermobaid, Ulm, Germany) derived from the most reactive epitope domains of gB, pp150, pp28, pp65 and pp38 were tested as described by Greijer et al. [31]. These five peptides were as follows: CMV-envelope component (gB), matrix proteins (pp65, pp28, pp150) and fusion protein (pp38). The amino acid position of the five CMV peptides is shown in table 2 .

\section{EIA for the Detection of Peptide-Specific IgG Antibody}

EIA was performed as described by Greijer et al. [31]. Briefly, micro-EIA plates were coated with $1 \mu \mathrm{g} / \mathrm{ml}$ of the selected peptides in $50 \mathrm{~mm}$ sodium bicarbonate buffer $(\mathrm{pH} 9.6)$ for $16 \mathrm{~h}$ at $4{ }^{\circ} \mathrm{C}$. Free binding sites were saturated by incubation with $3 \%$ bovine serum albumin in phosphate-buffered saline (PBS). After $1 \mathrm{~h}$ of incubation at $37^{\circ} \mathrm{C}$, wells were washed 4 times with PBS containing $0.05 \%$ Tween 20 (PBST). Sera were diluted 1:100 in PBST with $20 \%$ normal goat serum containing $0.5 \%$ Triton $\mathrm{X}-100$, and the mixture was incubated for $1 \mathrm{~h}$ at $37^{\circ} \mathrm{C}$. After washing, horseradish peroxidase-conjugated antibody to human IgG (The Binding Site, Birmingham, UK) diluted 1,000 times with PBST containing $1 \%$ bovine serum albumin was added for $1 \mathrm{~h}$. Wells were washed four times with PBST and the bound horseradish peroxidase label was detected with $3,3^{\prime}, 5,5^{\prime}$-tetramethylbenzidine as substrate for $30 \mathrm{~min}$ in the dark, after which the color reaction was stopped by the addition of $1 \mathrm{M} \mathrm{H}_{2} \mathrm{SO}_{4}$. Absorbance was measured at $450 \mathrm{~nm}$ by an EIA reader. The test was considered positive when the mean optical density values were more than twice the mean of the antigen control values.

\section{Statistical Analysis}

All statistical analysis was carried out using the SPSS software package (SPSS Inc. 2002, version 11.5.1, Chicago, Ill., USA). Proportions were analyzed by Fisher's exact probability test $(2 \times 2$ contingency table), the $\mathrm{p}$ values are two-sided.

Table 2. Description of CMV peptide antigens used in this study

\begin{tabular}{lc}
\hline CMV peptide antigens & Amino acid positions \\
\hline gB (UL55) & $792-809$ \\
pp28 (UL99) & $60-81$ \\
& $15-45$ \\
pp150 (UL32) & $130-160$ \\
& $595-614$ \\
& $615-636$ \\
pp65 (UL83) & $595-636$ \\
pp38 (UL80a) & $1011-1048$ \\
\hline
\end{tabular}

Table 3. EIA reactivity of serum samples to the five CMV-related antigens

\begin{tabular}{|c|c|c|c|c|c|}
\hline \multirow[t]{2}{*}{ Antigens } & \multicolumn{2}{|c|}{ Antigen-negative group $(n=46)$} & \multicolumn{2}{|c|}{ Antigen-positive group $(\mathrm{n}=23)$} & \multirow[t]{2}{*}{ p value ${ }^{2}$} \\
\hline & positive $^{1}$ & $\begin{array}{l}\text { average of } \\
\text { OD values }\end{array}$ & positive $^{1}$ & $\begin{array}{l}\text { average of } \\
\text { OD values }\end{array}$ & \\
\hline pp65 & $14(30.4)$ & 0.192 & $5(21.7)$ & 0.056 & 0.572 \\
\hline $\mathrm{gB}$ & $9(19.5)$ & 0.139 & $10(43.5)$ & 0.085 & 0.048 \\
\hline pp150 & $28(60.9)$ & 0.383 & $9(39.1)$ & 0.174 & 0.125 \\
\hline pp28 & $26(56.5)$ & 0.282 & $9(39.1)$ & 0.149 & 0.208 \\
\hline pp38 & $8(17.4)$ & 0.103 & $2(8.7)$ & 0.069 & 0.477 \\
\hline pp150/28 & $22(47.8)$ & NA & $1(4.3)$ & NA & $<0.001$ \\
\hline pp150 and 65 & $11(23.9)$ & NA & $1(4.3)$ & NA & 0.050 \\
\hline pp150 and 38 & $7(15.2)$ & NA & 0 & NA & 0.086 \\
\hline pp65 and 28 & $12(26.1)$ & NA & $2(8.7)$ & NA & 0.119 \\
\hline pp28 and 38 & $9(19.5)$ & NA & $1(4.3)$ & NA & 0.148 \\
\hline pp65 and gB & 0 & NA & $1(4.3)$ & NA & 0.333 \\
\hline pp150 and gB & $7(15.2)$ & NA & $5(21.7)$ & NA & 0.517 \\
\hline pp38 and gB & 1 & NA & 0 & NA & 0.999 \\
\hline pp28 and gB & $4(8.7)$ & NA & $3(13.0)$ & NA & 0.679 \\
\hline pp65 and 38 & $3(6.5)$ & NA & $1(4.3)$ & NA & 1.000 \\
\hline
\end{tabular}

NA $=$ Not applicable. ${ }^{1}$ Number and percentage (in parentheses). ${ }^{2}$ Fisher's exact test. 


\section{Results}

The results of the 69 patients are summarized in table 3. Antibodies to the gB antigen were present in 10 of $23(43.5 \%)$ and in 9 of $46(19.6 \%)$ antigen-positive and -negative recipients, respectively, and this difference was statistically significant $(\mathrm{p}=0.048)$. Regarding the other CMV-related peptide antigens pp65, pp150, pp28 and pp38 there was no statistically significant difference between the two groups as calculated by Fisher's exact probability test.

When combining the presence of antibodies to CMVrelated antigens we found that $22(48 \%)$ of the antigennegative KR had antibodies to both the pp150 and the pp28 antigens while among the antigen-positive kidney transplant recipients, only 1 patient reacted with these two antigens. The difference between the two groups was highly significant $(\mathrm{p}<0.001)$. The other combinations that resulted in no significant difference include pp65 and 150 , pp65 and 28, pp150 and 28, pp28 and 38, pp65 and $38, \mathrm{gB}$ and $\mathrm{pp} 150, \mathrm{gB}$ and $28, \mathrm{gB}$ and 38 and pp150 and 38 antigens are also shown in table 3.

CMV infection/reactivation occurring after transplantation triggered the production of antibodies to the CMV-peptide antigens. A number of those KR who were negative just prior to the detection of CMV infection became positive for one or more CMV-peptide antigens after CMV infection. This 'seroconversion' to the five antigens is shown in table 4.

\section{Discussion}

Humoral antibody responses of KR to major structural and nonstructural CMV-specific antigens seem to be correlated with the outcome of CMV infection/disease. Indeed a strong correlation between the presence of antibodies to the two peptide antigens (pp150/pp28) and the development of an active CMV infection/reactivation suggests that $\mathrm{CMV}$-antigen-specific humoral immune responses before transplantation may be used as markers regarding the outcome of CMV infection after kidney transplantation.

It is well established that CMV-specific antibodies cannot prevent virus dissemination in an immune-compromised host [32]. However, various studies have provided evidence that antiviral antibodies have a modulatory effect on the infection and the subsequent clinical course of CMV disease $[33,34]$. In the murine CMV system, neutralizing antibodies effectively limit viral spread
Table 4. Antibodies of KR in relation to the results of the antigenemia assay

\begin{tabular}{llc}
\hline $\begin{array}{ll}\text { CMV peptide } \\
\text { antigens }\end{array}$ & \multicolumn{2}{l}{ Antigen-positive group $(\mathrm{n}=23)$} \\
\cline { 2 - 3 } & $\begin{array}{l}\text { antibodies positive } \\
\text { prior to CMV infection }\end{array}$ & $\begin{array}{l}\text { antibodies positive } \\
\text { after CMV infection }\end{array}$ \\
\hline pp65 & $4(17.4)$ & $5(21.7)$ \\
gB & $5(21.7)$ & $10(43.5)$ \\
pp150 & $6(26.1)$ & $9(39.1)$ \\
pp28 & $4(17.4)$ & $9(39.1)$ \\
pp38 & $1(4.3)$ & $2(8.7)$ \\
\hline
\end{tabular}

Number and percentage (in parentheses) are given.

during reactivation, an effect that is dependent on antibody titer $[32,35]$. A similar situation seems to exist in bone marrow transplant patients; high CMV glycoprotein-specific antibody titers were associated with the absence of PCR positivity, indicating an effective suppression of viral dissemination [36]. Thus, in situations in which transplant recipients maintained or developed high CMV glycoprotein-specific humoral immune responses, viral replication could not be detected and clinical symptoms related to CMV infection were not seen. These results are in agreement with the findings published in relation to liver transplantation [37].

\section{Conclusion}

Data of the study suggest that the combined presence of antibodies against pp150 and pp28 antigens may indicate a lower risk of CMV infections/reactivation after kidney transplantation.

References

1 Sarmiento JM, Dockrell DH, Schwab TR, Munn SR, Paya CV: Mycophenolate mofetil increases cytomegalovirus invasive organ disease in renal transplant patients. Clin Transpl 2000;14:136-138.

2 Bolovan-Fritts CA, Mocarski ES, Wiedeman JA: Peripheral blood CD14(+) cells from healthy subjects carry a circular conformation of latent cytomegalovirus genome. Blood 1999;1:394-398.

-3 Boppana SB, Britt WJ: Antiviral antibody responses and intrauterine transmission after primary maternal cytomegalovirus infection. J Infect Dis 1995;171:1115-1121. 
4 Snydman DR: Cytomegalovirus immunoglobulins in the prevention and treatment of cytomegalovirus disease. Rev Infect Dis 1990;7:S839-S848.

$\checkmark 5$ Meyers JD, Flournoy N, Thomas ED: Risk factors for cytomegalovirus infection after human marrow transplantation. J Infect Dis 1986;153:478-488.

6 Rubin RH, Russell PS, Levin M, Cohen C: From the National Institutes of Health. Summary of a workshop on cytomegalovirus infections during organ transplantation. J Infect Dis 1979;139:728-734.

7 Dummer JS, White LT, Ho M, Griffith BP, Hardesty RL, Bahnson HT: Morbidity of cytomegalovirus infection in recipients of heart or heart-lung transplants who received cyclosporine. J Infect Dis 1985;152:11821191.

$>8$ Razonable RR, Rivero A, Rodriguez A, Wilson J, Daniels J, Jenkins G, Larson T, Hellinger WC, Spivey JR, Paya CV: Allograft rejection predicts the occurrence of late-onset cytomegalovirus (CMV) disease among CMV-mismatched solid organ transplant patients receiving prophylaxis with oral ganciclovir. J Infect Dis 2001;184:1461-1464.

$>9$ Borysiewicz LK, Hickling JK, Graham S, Sinclair J, Cranage MP, Smith GL, Sissons JG: Human cytomegalovirus-specific cytotoxic T cells: relative frequency of stage-specific CTL recognizing the $72-\mathrm{kD}$ immediate early protein and glycoprotein B expressed by recombinant vaccinia viruses. J Exp Med 1988;168:919-931.

$>10$ Jonjic S, Pavic I, Plic B, Crnkovic I, Lucin P, Koszinowski UH: Antibodies are not essential for the resolution of primary cytomegalovirus infection but limit dissemination of recurrent virus. J Exp Med 1994;179:17131717.

- 11 Essa S, Raghupathy R, Pacsa AS, El-Shazly A, Said T, Azizieh F: Th1-type cytokines production is decreased in kidney transplant recipients with active cytomegalovirus infection. J Med Virol 2000;60:223-229.

$>12$ Essa S, Pacsa AS, Al-Attiyah R, El-Shazly A, Raghupathy R, Said T: The use of flow cytometry for the detection of CMV-specific antigen (pp65) in leukocytes of kidney recipients. Clin Transpl 2000;14:147-151.

- 13 Van Zanten J, De Leij L, Prop J, Harmsen MC, The TH: Human cytomegalovirus: a viral complication in transplantation. Clin Transpl 1998;12:145-158.

- 14 Cosimi AB, Colvin RB, Burton RC, Rubin RH, Goldstein G, Kung PC, Hansen WP, Delmonico FL, Russell PS: Use of monoclonal antibodies to T-cell subsets for immunologic monitoring and treatment in recipients of renal allografts. N Engl J Med 1981;305 308-314.

-15 Ljungman P, Niederwieser D, Pepe MS: CMV infection after marrow transplantation for aplastic anemia. Bone Marrow Transplant 1990;6:295-300.
16 Meyers JD, Flournoy N, Thomas ED: Risk factors for CMV infection after human marrow transplantation. J Infect Dis 1986;153: 478-488.

17 Pass FR, Reynolds DW, Welchel JD, Diethelm AG, Alford CA: Impaired lymphocyte transformation response to CMV and phytohemagglutinin in recipients of renal transplant: association with antithymocyte globulin. J Infect Dis 1981;143:259-265.

18 Landini MP, Guan MX, Jahn G, Lindenmaier W, Mach M, Ripalti A, Necker A, Lazzarotto T, Plachter B: Large-scale screening of human sera with cytomegalovirus recombinant antigens. J Clin Microbiol 1990;28: 1375-1379.

19 Goossens VJ, Vink C, Mullers W, Middeldorp JM, Bruggeman CA: Different profiles of cytomegalovirus RNA transcripts and anti-cytomegalovirus IgM antibodies in renal transplant recipients. J Clin Virol 2001; 23:87-95.

20 Muller TF, Gicklhorn D, Jungraithmayr T, Eickmann M, Lange H, Radsak K, Reschke $\mathrm{M}$ : Pattern and persistence of the epitopespecific IgM response against human cytomegalovirus in renal transplant patients. J Clin Virol 2002;24:45-56.

21 Forman SJ, Zaia JA, Clark BR, Wright CL, Mills BJ, Pottathil R, Racklin BC, Gallagher MT, Welte K, Blume KG: A 64000 Da matrix protein of human cytomegalovirus induces in vitro immune responses similar to those of whole viral antigen. J Immunol 1985;134: 3391-3395.

22 Landini MP, Ripalti A, Sra K, Pouletty P: Human cytomegalovirus structural proteins: immune reaction against pp150 peptides. J Clin Microbiol 1991;29:1868-1872.

23 Kraat YJ, Stals FS, Christiaans MHL, Lazzarotto T, Landini MP, Bruggeman CA: IgM antibody detection for pp38 (UL80a) and 150 (ppUL32) kDa proteins by immunoblotting: the earliest parameter for acute cytomegalovirus infection in renal transplant recipients. J Med Virol 1996;48:289-294.

$24 \mathrm{He}$ H, Rinaldo CR, Morel PA: T cell proliferative responses to five human cytomegalovirus proteins in healthy seropositive individuals: implications for vaccine development. J Gen Virol 1995;76:1603-1610.

25 Sylwester AW, Mitchell BL, Edgar JB, Taormina C, Pelte C, Ruchti F, Sleath PR, Grabstein KH, Hosken NA, Kern F, Nelson JA, Picker LJ: Broadly targeted human cytomegalovirus-specific CD4+ and CD8+ T cells dominate the memory compartments of exposed subjects. J Exp Med 2005;5:673685.

26 Beninga J, Kropff B, Mach M: Comparative analysis of fourteen individual human cytomegalovirus proteins for helper $\mathrm{T}$ cell response. J Gen Virol 1995;76:153-160.
27 Alp NJ, Allport TD, VanZanten J, Rodgers B, Sissons JGP, Borysiewicz LK: Fine specificity of cellular immune responses in human to human cytomegalovirus immediate-early 1 protein. J Virol 1991;65:4812-4820.

28 Curtsinger JM, Liu YN, Radeke R, Bryon MK, Fuad S, Bach FH, Gehrz RC: Molecular analysis of the immune response to human cytomegalovirus glycoprotein B (gB). II. Low gB-specific $\mathrm{T}$ and $\mathrm{B}$ cell responses are associated with expression of certain HLADR alleles. J Gen Virol 1994;75:301-307.

29 Liu YN, Klaus A, Kari B, Stinski MF, Eckhardt J, Gehrz RC: The N-terminal 513 amino acids of the envelope glycoprotein $\mathrm{gB}$ of human cytomegalovirus stimulates both Band T-cell immune responses in humans. J Virol 1991;65:1644-1648.

30 van der Bij W, Torensma R, van Son WJ, Anema J, Schirm J, Tegzess AM, The TH: Rapid immunodiagnosis of active cytomegalovirus infection by monoclonal antibody staining of blood leucocytes. J Med Virol 1988;25: 179-188

31 Greijer AE, van de Crommert JM, Stevens SJ, Middeldorp JM: Molecular fine-specificity analysis of antibody responses to human cytomegalovirus and design of novel syntheticpeptide-based serodiagnostic assays. J Clin Microbiol 1999;37:179-188.

32 Jonjic S, Pavic I, Polic B, Crnkovic I, Lucin P, Koszinowski UH: Antibodies are not essential for the resolution of primary cytomegalovirus infection but limit dissemination of recurrent virus. J Exp Med 1994;179:17131717.

33 Siadak MF, Kopecky K, Sullivan KM: Reduction in transplant-related complications in patients given intravenous immunoglobulin after allogeneic marrow transplantation. Clin Exp Immunol 1994;97(suppl 1):53-57.

34 Adler SP, Starr SE, Plotkin SA, Hempfling $\mathrm{SH}$, Buis J, Manning ML, Best AM: Immunity induced by primary human cytomegalovirus infection protects against secondary infection among women of childbearing age. J Infect Dis 1995;171:26-32.

35 Reddehase MJ, Balthesen M, Rapp M, Jonjic S, Pavic I, Koszinowski UH: The conditions of primary infection define the load of latent viral genome in organs and the risk of recurrent cytomegalovirus disease. J Exp Med 1994;179:185-193.

36 Schoppel K, Schmidt C, Einsele H, Hebart H, Mach M: Kinetics of the antibody response against human cytomegalovirus-specific proteins in allogeneic bone marrow transplant recipients. J Infect Dis 1998;178:12331243.

37 Schoppel K, Kropff B, Schmidt C, Vornhagen $\mathrm{R}$, Mach M: The humoral immune response against human cytomegalovirus is characterized by a delayed synthesis of glycoprotein-specific antibodies. J Infect Dis 1997; 175:533-544. 